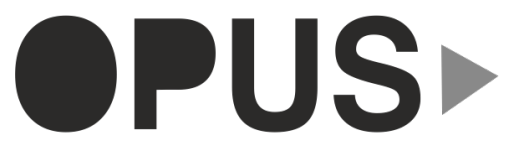

Uluslararası Toplum Araştırmaları Dergisi International Journal of Society Researches
E-ISSN : 2528-9535

YIl Year: 9

Cilt Volume: 14

Sayı Issue :20

Aralık December 2019

Makalenin Gelis Tarihi Received Date: 05/08/2019

Makalenin Kabul Tarihi Accepted Date: 12/12/2019

\title{
Dijital Medya Okuryazarlığında Anne ve Baba Eğitimi
}

\author{
DOI: 10.26466/opus.601942
}

$*$

\author{
Mehmet Tahir Karaboğa * \\ * Dr. Öğr. Üyesi, Mersin Üniversitesi, Eğitim Fakültesi, Mersin/Türkiye \\ E-Posta: tahirkaraboga@gmail.com \\ ORCID: 0000-0003-0795-7991 \\ Öz
}

Bilgisayar, cep telefonu, internet gibi dijital medya araçlarının yoğun olarak kullanıldığg bir çağda yaşıyoruz. Bu araçların gelişip yaygınlaşmasıyla beraber, sosyal ilişkiler, bireysel yaşam ve özellikle aile ilişkileri dönüşüme uğradı. Bilgisayar temelli bir medya olan dijital medyanın etkileri gün geçtikçe daha fazla ön plana çıkmaya başlamıştır. Cep telefonu, tablet, bilgisayar üzerinden anne-baba ve çocukların internet ortamlarında sınırsız sayıda medya içeriğine ulaşabilmesi ve yoğun bir şekilde tüketmesinin aile ilişkileri ve iletişim biçimleri üzerinde çeşitli sonuçları olabilmektedir. Dijital medya okuryazarlığı konusunda anne ve babalarm eğitilmesi ve bilinçlendirilmesi, medya okuryazarlı̆̆ı eğitiminin önemli bir ayağın oluşturmaktadır. Günümüzde her yaşta aile bireyinin, dijital teknolojiler ile ilişkilerinde sosyal ve bireysel bir takım problemler, riskler yaşamamaları adına bilinçli bir medya okuryazarı olması bir zorunluk olarak karşımıza çıkmaktadır. Dijital okuryazarlık, iletişim teknolojilerinin olumlu özelliklerini geliştirerek, olumsuz taraflarım en aza indirmeyi amaçlar. Dijital medya ortamlarındaki sorunlar ve kullanım riskleri konusunda uzmanlar önemli tartı̧̧malar yürütmekte bu konuda nitelikli bir dijital medya okuryazarl $\breve{g}$ l, içinde bulunduğumuz çă̆ın olmazsa olmazları arasında önerilmektedir. Bu çerçevede bu çalışmada anne ve babaların neden dijital medya okuryazarı olmalarn gerektiği, dijital medyanın aile ilişkileri ve çocuk gelişimine etkileri, dijital okuryazar anne ve baba olmanın aile ilişkileri ve çocuk eğitimine sağlayacağı katkılar hakkında bir tartışma yürütülmektedir.

Anahtar Kelimeler: Dijital Medya, Aile, Dijital Medya Okuryazarlığı 


\title{
Parent Education in Digital Media Literacy
}

\begin{abstract}
We live in an age where digital media such as computers, mobile phones and the internet are used extensively. With the development and spread of these media means, social relations, individual life and especially family relations have been transformed. The effects of computer-based digital media have become more and more prominent. The fact that parents and children can access to an unlimited number of media content on the internet and consume intensively through mobile phones, tablets and computers may have consequences on family relations and communication styles. The education and awareness raising of parents on digital media literacy is an important part of media literacy education. Today, it is a necessity for the family members of all ages to be a conscious media literate in order to avoid social and individual problems and risks in their relations with digital technologies. Digital literacy aims to minimize the negative aspects of communication technologies by developing positive features. Experts conduct important discussions on the problems and risks of digital media usage and a qualified digital media literacy is recommended as one of the indispensables of our time. In this context, in this study, there is a discussion about why parents should be digital media literate, the effects of digital media on family relations and child development, the contribution of digital literate parents to family relations and child education.
\end{abstract}

Keywords: Digital Media, Family, Digital Media Literacy 


\section{Giriş}

Dijital bir çağda yaşıyoruz. Dijital medya araçlarının kullanımının her geçen gün daha fazla artış gösterdiği, etkilerinin her gün daha fazla hissedildiği bu dönemde medyanın işleyişi ve içeriklerini daha iyi anlamamız gerekmektedir. Bu çağda medya teknolojileri toplumsal yaşamın her anına nüfuz ederek her yaştan bireyin hayatını etkilemekte, dönüştürmekte ve onların yaşam tarzında ve günlük hayatında derin izler bırakmaktadır. Özellikle aile bireylerinin ilişkileri bu süreçten oldukça etkilenmektedir. Aileler ve anne babalar, çocukların hayatlarına giren yeni dijital teknolojilerin olumsuz etkilerinden onları nasıl koruyabilecekleri konusunda yetersiz kalabilmektedir. Çocuğun medya ile ilişkisinde ortaya çıkan pek çok sorunun çözülmesi, aile içi ilişkilerin düzenlenmesi noktasında anne ve babaların medya eğitimi alması zorunlu hale gelmektedir.

İnsanlar bilgisayar, tablet, akıllı telefon gibi dijital medya araçları ile dijital medya ortamlarına (internet) bağlanıp televizyon izleyebilmekte, gazete okuyabilmekte, haber takip edebilmekte, fotoğraf, video yükleyip paylaşabilmekte, oyun oynayabilmekte, anında 24 saat iletişim halinde olabilmektedir. Bireylerin cep telefonu, bilgisayar ile internet kullanımı yaygınlaştıkça bu araçları kullanma süreleri de artmaktadır. İçinde bulunduğumuz yüzyılda bilişim teknolojileri insanın gündelik yaşamın ayrılmaz bir parçası haline gelmiş, internet bağımlılığı, dizi film bağımlılığı, oyun bağımlılığı, sosyal medya bağımlılığı, selfie bağımlılı̆̆1 gibi bir dizi izleme ve kullanma bağımlılığı tüm bireyleri özellikle de çocukları ve gençleri tehdit eden bir olgu haline gelmiş bulunmaktadır. Aileler bir yandan çocukların yeni medya araçları ile içli dışlı olmasını teşvik ederken diğer yandan bu teknolojilerin kullanımından kaynaklandığı düşünülen sorunların varlığından ciddi şekilde endişelenmektedir.

Çocuk, aile ve çevresiyle kurduğu sağlıklı ilişkiler sayesinde yaşadığı ortamın ve genel olarak da toplumun sosyo-kültürel değerlerini benimser ve sosyal ilişkilerde ortak bir iletişim dilini kullanmayı başarır. Böylece çocuk, toplumun bir üyesi olarak o toplumun kültür ve değerlerini geleceğe taşıma rolünü üstlenir. Günümüzde insanların yoğun iş tempoları ve iş dışı bazı aktiviteleri aile içi ortak zamanları kısıtlamakta, bireyler 
yalnızca akşamları bir araya gelebilmektedir. Ancak akşam birlikteliğini değerlendiremeyen ve aynı ortamda bulunduğu hale iletişim kurmadan yaşayan aile örnekleri ortaya çıkmaktadır. Ailedeki sağlıklı iletişim, öncelikle anne-babanın iletişimiyle doğrudan ilgili olup sağlıklı anne-baba iletişimi, aynı zamanda sağlıklı çocuk anlamında da gelmektedir. Geleceğin sağlıklı ailesi, yine sağlıklı iletişim kurabilen bir ailenin içinde yetişen çocuklarla mümkün olmaktadır (Güleç, 2018). Bu nedenle toplumun en küçük yapı taşı olan ailenin huzurlu, mutlu bir şekilde varlığını devam ettirebilmesi ve sağlıklı nesiller yetiştirebilmesi için anne babaların, günümüzün en önemli toplumsal olgulardan biri olan dijital medya konusunda bilgi ve donanım sahibi olması gerekmektedir. Çocukların önce ailede sonra okul yaşantılarında devam edecek bir medya eğitimi ile bilinçli medya kullanıcıları olmaları temel olarak bilinçli ebeveynlerin katkısını gerektirmektedir.

\section{Dijital Medya Kavramı}

Medya kavramını genel anlamda; bireyleri haberdar etme, bilgilendirme, eğitme, eğlendirme gibi işlevleri olan kitle iletişim araçları olarak tanımlayabiliriz. Günümüzde medyayı klasik medya ve dijital medya olarak ikiye ayırmak mümkündür. Klasik medya; gazete, dergi, radyo ve analog televizyon gibi araçlardan meydana gelirken, dijital medya ise akıllı telefon, tablet, dijital televizyon, bilgisayar gibi araçlarla girilen internet tabanlı her türlü yazılı, görsel ve işitsel ortamı kapsamaktadır. Kanat'a (2016) göre, "dijital medya, bilgisayar ortamında sayısal olarak kodlanmış her türlü ses, video, yazı ve fotoğraf içeriğini ve benzeri materyali ifade eder. Bilgisayar programları, oyunlar, dijital ses dosyaları, ekitaplar, dijital medya materyalleri arasında akla ilk gelenlerdir. Dijital medya terimiyle insanların elektronik, yani bilgisayar ve benzeri cihazlarla, dijital olarak iletişim kurma şekilleri kastedilir. Bu anlamıla elektronik ortamda bulunan her tür kitle iletişim aracını dijital medya tanımına dâhil etmek mümkündür" (s.531). Klasik medya daha çok analog teknolojiye dayanırken yeni medya kavramı ise daha çok dijital teknolojiye dayanır. Dijital medyayı, bilgisayar temelli bir medya olarak betimlemek mümkündür. Dijital medyanın etkileri gün geçtikçe ön plana çıkmaktadır. Medyanın dijitalleşmesini ve yaygınlaşmasını sağlayan şey 
internet teknolojisi olmuştur. Toplumsal hayatı değiştiren dijital medya, klasik analog medya araçlarından kendine has özellikleri ile farklılık göstermektedir. Buna göre "dijital teknoloji tek yönlü değildir, karşılıklı iletişimi mümkün kılabilmekte, ayrıca bu karşılıklı iletişim olanağ kitle iletişimi içerisinde kişiyle özel iletişim kurabilme imkânını da sunabilmektedir. Dijital medyayla bir yayın kaydedip saklayarak sonra ya da tekrar izleyebiliriz. Dijital medyayla insanlar, iletişimi zamana yayabilme imkânıyla âdeta aralıksız iletişimde kalabilmektedirler" (Kanat, 2016, s.532).

Pratik olarak her konuda bilgi edinmeyi olanaklı kılan web sitelerine ulaşmayı sağlayan dünya çapında bir ağ olan internet, dijital medyanın bilinen yüzüdür. Ancak, dünya çapında bir ağa dönüşmeden önce birçok teknolojik altyapının kurulması gerekmiştir. İnternetten daha geniş kapsamlı olarak iletişim teknolojisini ifade eden 'dijital medya' kavramı, bilgi taşıyan, oyun-eğlence sunan, offline olarak da yararlanılan birçok bilgisayar destekli programı ifade etmektedir (Özkan, 2016). Özkan'a göre, "bilgi, haber, oyun ve eğlence kaynakları ve ortamları sağlayan dijital medya, rutin ve rutin olmayan hemen her işimizi yapmanın olanaklarını sunan bir ortam sunmaktadır. Dijital medya ağı ve teknolojilerinin yaşlı çocuk demeden herkese ulaşması ve herkesi birer kullanıcı ya da etkileyen yapmasıyla artık yeni bir çağı, "dijital çağ" 1 yaşadığımız yaygın olarak kabul edilmektedir" (s. 83).

Türkiye'de internet, sosyal medya ve mobil telefon kullanıcı sayısı oldukça fazladır. We Are Social araştırma şirketinin 2018 Türkiye'de internet, sosyal medya ve mobil telefon kullanıcı istatistiklerine baktığımızda; internet kullanıcı sayısının 54.3 milyon, aktif sosyal medya kullanıcısı sayısının 51 milyon, aktif mobil sosyal medya kullanıcı sayısının ise 44 milyon kişi olduğu belirtilmiştir. Araştırmaya göre, insanlar internette günde ortalama 7 saat geçirirken, günde ortalama 2 saat 48 $\mathrm{dk}$. sosyal medyada, günde ortalama 2 saat $44 \mathrm{dk}$. televizyon başında, günde ortalama 1 saat $22 \mathrm{dk}$. müzik dinleyerek zaman geçirmektedir. Türkiye'de 2018 yılı internet kullanım istatistiklerine baktı̆̆ımızda; Türkiye'de, nüfusun \% 67'sine tekabül eden 54 milyon internet kullanıcisı bulunduğu ve bunların 51 milyonunun telefonlarından internete bağlanabildiği ifade edilmiştir. İnternet kullanıcılarının \% 36'sının masaüstü bilgisayar veya laptoplardan, \% 62'sinin mobil cihazlardan ve \%3'ünün 
tabletlerinden internete bağlanabildikleri, en aktif sosyal medya platformlarının ise sırasıyla Youtube, Facebook, Instagram ve Twitter olduğu belirtilmiştir (Dijilopedi, 2018).

Dijital medya ortamları pek çok insan için birçok cazip özellikler barındırabilmektedir. Neredeyse sınırsız sayıda bilgi, oyun ve eğlence imkânlarına kolayca erişim sağlayan dijital medya, sık ve uzun süre kullananları kendisine bağımlı kılabilmektedir. Bağımlılık boyutu, dijital medya ile ilgili yapılan tartışmalarda yöneltilen eleştirilerin başında gelmektedir. Bağımlılığın, özellikle aileler açısından çocukların okul ve ev yaşamları üzerinde bireysel yeteneklerin körelmesi anlamında büyük etkileri olabilmektedir. Özkan'a (2016) göre, “dijital medya araçları ve internet ağının yaygınlaşması, çocukların medyayla ilişki kurmasını kolaylaştırmaktadır. Bu kolaylık, çocukların sık sık ve uzun süreli medyanın etkilerine maruz kalmasına neden olmaktadır" (s.138).

Günümüzde dijital medya araçları yaşamımızın neredeyse ayrılmaz bir parçası haline gelmiştir. Bu durum, tüm bireylerin dijital medya araçlarına kolay ulaşmasına ve onları sık kullanmalarına olanak sağlamaktadır. Kablosuz ağların çoğalması ve bireylerin bu ağlara birçok yerde bağlanabilmesi, sınırları ortadan kaldırmıştır. Bireylerin medya araçlarına kolay ulaşabilmesi onların bu araçlarla daha çok zaman geçirmelerini kaçınılmaz bir hale getirebilmektedir. Günümüzde çocuklar, yetişkinler ve her yaşta birey, dijital medya araçlarıyla iç içe bir hayata başlamıştır.

Bireylerin bilgisayar ve interneti birçok amaç için normal sınırların üzerinde bir şekilde kullanmaya başlaması; yaşam tarzında, komşuluk ilişkilerinde, yüz yüze iletişimde değişmeler meydana getirmiştir. Bireylerin dijital medya kullanma alışkanlıkları aynı zamanda onların fizyolojik, zihinsel ve kişisel yaşamları üzerinde olumsuz etkiler bırakabilmektedir. Günümüzde akrabalık ilişkileri, komşuluk bağları zayıflamış ve kimi zaman da bu bağların kopma noktasına geldiği görülmüştür. Kaya, Bensghir ve Altınok (2012), internetin aile kurumunu ve ilişkilerini de derinden etkilediğini belirtmekte ve internet ortamlarındaki risklere dikkat çekmeye çalışmaktadır. Bu riskler şu şekilde sıralanmaktadır: İstenmeyen içerik (pornografik, yasal olmayan örgütlerin propagandası vb.), kişisel bilgilerin/şifrelerin çalınma riski, kötü niyetli sanal (chat) arkadaşlıktan doğacak riskler, spam mail ve istenmeyen mesaj içerikleri, internette amaçsiz uzun süre sörf yapma, internette uzun süre oyun oynama 
sonucu oluşan a-sosyal kişilik, evde iş yapan anneler, babalar ve giderek aile yaşamından uzaklaşan ebeveyn ve çocuklar. Kaya Bensghir ve Altınok'a (2012) göre, özellikle video oyunları, içeriğinde barındırdığı şiddet içerikleri sebebiyle kişilerin ruh sağlı̆̆ının bozulmasına neden olabilmekte, bağımlılık yapabilmekte ve bireyin yaşam kalitesini ciddi anlamda düşürebilmektedir. Özellikle çocuklar, videolarda ve oyunlarda gördükleri pek çok şeyi taklit edebilmekte, öykünebilmekte, kontrolsüz ve zararlı içeriklere maruz kalabilmektedir. Bu zararlar; yaralanma, ölüm riski, siber zorbalık, taciz gibi pek çok riski barındırabilmektedir.

\section{Dijital Medya Okuryazarlığı}

İçinde bulunduğumuz yüzyılda okuma-yazma kavramı, geleneksel anlamdaki okuma yazma kavramından oldukça farklılık göstermiştir. Aytaş ve Kaplan'a (2017) göre, "geleneksel anlamda okuryazar olmak harflerle kodlanmış yazılı metinleri okumak ve duygu düşüncelerin ayn kod sistemi aracılığıyla yazıya aktarılmasını ifade etmekteydi. Oysa modern okuryazarlık, farklı beceri ve gereklilikleri beraberinde getirmiştir" (s.293). Pek çok kimse için okuma-yazma bilmek, okuryazar olmakla eş anlama gelebilmektedir. Fakat "okuma-yazma, okuyucu tarafından yazılı materyal ile okuma durumunun kapsamı arasında iletişim kurmayı gerektiren bir süreçken, okuryazarlık bağlamlar arasında değişiklik yapabilmeyi ve becerilerin farklı bağlamlara aktarılması ya da aktarılmamasını ifade etmektedir" (Vacca ve Vacca'dan aktaran Gül, 2007, s.19). Aytaş ve Kaplan'a göre, "okuma-yazma bilmek yazılı metinlerin çözümlenmesi anlamına gelmekteyken okuryazarlık internet, teknoloji, görsel metinler, medya, bilgi vb. bir alanda bilgi sahibi olma ve söz konusu alanlardaki bilgiyi anlamlandırabilme yetisini ifade etmektedir" (Aytaş ve Kaplan, 2017, s.292).

Hobbs'e (2010) göre, dijital okuryazarlık kavramı, internet ortamlarında doğru bilgileri ve materyalleri doğru yöntemlerle ve doğru amaç için kullanabilmedir. Dijital medya okuryazarlığı kavramı ise; bilgisayar, tablet, akıllı telefon gibi araçlarla internet ortamlarındaki her türlü yazı, işitsel ve görsel habere, bilgiye ulaşma, bu haber ve bilgileri doğrulama, anlama, algılama, analiz etme, dönüştürme ve paylaşmayı içeren bir 
iletişim becerisi kazanma süreci olarak tanımlanır (Güleç, 2019). Bu anlamda dijital medya okuryazarlığı medya içeriklerinin anlaşılması, yorumlanması, bilgilerin üretilmesi, eleştirel becerinin geliştirmesi, kişinin medya içeriklerinden korunması ve medyayı etkin kullanma süreçlerini barındırır. Bilinçli bir dijital medya okuryazarı olmak, her yaşta birey tarafından kazanılması gereken çağımızın en önemli becerilerinden birisidir.

Güleç'e göre, iyi bir dijital medya okuryazarı olabilmenin temel kurallarından biri, eleştirel düşünme becerisine sahip olmakla mümkündür. Bilinçli bir dijital medya okuryazarının, internet ortamında kendisine sunulan her türlü bilgi ve haberi eleştirel bir bakış açısıyla sorgulayabilmesi, bilginin kaynağını araştırıcı, analitik bir yaklaşımla irdelemesi zihin dünyasına yönelik muhtemel riskleri analiz etmesi beklenir (Güleç, 2019). Yaşadığımız dijital çağda başta çocuklar ve gençler olmak üzere her bireyin sosyal ve kişisel hayatında bir takım problemler, riskler yaşamaması adına bilinçli birer medya okuryazarı olması bir zorunluk haline gelmektedir. Özkan'a (2016) göre, “Radyo, televizyon, sinema gibi analog yapıya sahip iletişim araçlarının tek yönlü ileti gönderme özelliklerinin aksine dijital medya araçları çift yönlü etkileşimlere olanak sağlamaktadır. Bilgisayar, telefon, fax ve internet gibi birçok medya aracının işlevlerinin toplandığı akıllı cep telefonlarının yaygınlaşmasıyla herkes gibi çocuklar da bunlara kolay ulaşmaktadır. Dijital medya araçlarına çocukların kolay ulaşması, çocukların bu araçları kullanmaktan doğan olumsuz etkilere maruz kalmasını kolaylaştırmaktadır" (s.3). Dijital ortamlarda pek çok faydalı içerik bulunmasına rağmen olumsuz birçok içeriğin de bulunduğunu söylememiz mümkündür. Bu anlamda iyi bir dijital medya okuryazarı olmak, içinde bulunduğumuz çağın önemli gereklilikleri arasında görülmektedir. İrvan'a (2017) göre, dijital okuryazarlık ve medya okuryazarlığı, dijital medyanın olumlu özelliklerinden faydalanmamızı sağlarken, birey üzerindeki olumsuz etkileri en aza indirmeyi amaçlar. Hobbs, dijital ortamların çocukların ve gençlerin sağlıklı gelişimi, mahremiyetleri, fiziksel ve psikolojik güvenlikleri açısından sakıncalı, rahatsız edici materyaller barındırdığını söylemektedir. Ancak bunun yanında yararlı pek çok materyalin de olduğunu, bu anlamda insanların interneti eğitim amaçlı olarak doğru yararlanabilmeleri için bilginin bu ortamlarda nasıl inşa edildiğini, oluşturulduğunu, nasıl bir bakış 
açısını temsil ettiğini iyi bilmeleri gerektiğini ifade etmektedir. Hobbs'e göre, dijital teknolojiler, insanların yalnızca çocukluk döneminde değil, aynı zamanda bir ömür boyu tutumlarını, davranışlarını ve değerlerini şekillendirmelerine de katkıda bulunduğundan, potansiyel zararları ele alma konusunda bilgilenmeye ihtiyaç vardır (Hobbs, 2010).

\section{Dijital Medya Okuryazarlığında Aile}

TDK (2019), aile kavramını "evlilik ve kan bağına dayanan, karı, koca, çocuklar, kardeşler arasındaki ilişkilerin oluşturduğu toplum içindeki en küçük birlik, aynı soydan gelen veya aralarında akrabalık ilişkileri bulunan kimselerin tümü, birlikte oturan hısım ve yakınların tümü" olarak tanımlanmaktadır. Aile, çocuğun ilk dünyaya geldiği, ilk eğitimini, bilgilerini, deneyimlerini edindiği temel toplumsal bir kurumdur. Toplumsal yapıdaki en temel işlevleri de aile üstlenmiştir. Çocukların biyolojik, psikolojik bakımdan korunması ve yetiştirilmesi, sosyalleştirilmesi, gerekli bilgi ve becerilerin kazandırılması, toplumsal değer ve normların, tutum ve davranışların öğretilmesi ailenin temel işlevlerindendir. Aile ortamında çocuğun rol modeli anne ve babadır. Çocuklar anne ve babayı gözlemleyerek davranışlarını, giyimlerini, konuşmalarını taklit eder. Anne ve babanın yaklaşımı, tutumu ve hayata bakışları çocuğun gelişiminde belirleyici bir rol oynayabilmektedir. Ailenin çocukla ilişki kurması, konuşması, kişilik gelişiminde dışa veya içe dönük olmasını etkileyebilmektedir. Düzen ve uyum içinde işleyen mutlu bir toplumun temeli ailede anne ve babaya verilecek eğitimden geçer. Demokratik bir toplum yaratmanın temeli de demokratik bir aileden geçer. Yaratıcı ve üretici bir bireyin yaratılmasında aile temel bir rol üstlenmiştir.

Çocuk eğitimi her aile için önemli olan bir konudur. Özyürek ve Şahin'e göre, "çocukların yetişmesi ve toplum tarafından kabul görmesi noktasında ailelere büyük görev ve sorumluluklar düşmektedir. Anne ve babalarının tutum ve davranışları, yetiştikleri ortam ve demografik özellikleri çocuğun kişilik özelliklerini derinden etkileyebilmektedir" (Özyürek ve Şahin, 2005, s.20). Anne ve babaların ilk çocukluk döneminde çocuklara karşı gösterdikleri davranışlar çocuklarının kişilik özelliklerinin oluşmasında önemli rol oynar. Özel ve Zelyurt'a göre (2016, s.12), "aile içerisinde iyi bir iletişimin olması için ilk olarak ebeveynlerin çocuklarını 
fiziksel, ruhsal ve sosyal açlardan çok iyi tanıması gerekir. Böylece çocuğunun hangi konuda, ne kadar ve nasıl bir rehberliğe ihtiyacı olduğunu bilir ve ona göre davranır".

Çocuklar, anne ve babayı gözlemleyerek davranışlarınımodel aldıklarından anne ve babalar gelecekte dijital medya kulanımı konusunda çocukların tutumlarının şekillenmesinde temel oluşturabilirler. Çocukların ilerde medya bağımlısı olmaması, sağlıklı kişilik gelişimlerinin gerçekleşmesi, dışa dönük sağlıklı, yaratıcı bir birey şeklinde yetişmesi adına, anne-baba aile içinde hazılayıcı rol üstlenebilir.

\section{Ailede Anne ve Babanın Dijital Medya Okuryazarlı̆̆ı Ĕ̆itimi Alma Gerekliliği}

Dijital medyanın, aile ilişkilerini etkilemesi ve değiştirmesi anne ve babanın dijital medya okuryazarı olmasını gerektiren önemli sebeplerin başında gelmektedir. Aile bireylerinin ev ortamında yoğun olarak cep telefonu, televizyon ve bilgisayar ekranları karşısında farklı medya program içeriklerini tüketerek zaman geçirmeleri, bir takım sonuçları ortaya çıkarabilmektedir. Bu durum aile bireylerinin birbirleriyle iletişim kurmalarını zorlaştırabilmekte, aile bağları körelebilmekte, aile ortamında konuşulması gereken konular konuşulmadan geçip gitmekte, şefkat ve ilgi ihmal edilebilmektedir. Aile bireylerinin yoğun dijital medya araçlarını kullanması bireylerin ailelerine ve arkadaşlarına ayırmaları gereken zamanı azaltabilmekte, dijital araçlara olan bağımlılık riski artabilmekte ve aile ortamında yeni bir yaşam tarzı ortaya çıkabilmektedir. Sosyal çevreden kopma, akrabalık ve arkadaşlık ilişkilerinde zayıflama, yüz yüze ve samimi ilişkilerde azalma, yalnızlık, depresyonda artış, eşler arasındaki güvensizlik diğer sonuçlardır.

Ailede anne ve babaların neden dijital medya okuryazarlığı eğitimi almaları gerektiğine ilişkin diğer bir neden de dijital medyanın çocukları fiziksel, zihinsel, psikolojik ve kültürel olarak etkileyebilmesi konusudur. Çocuklar çok erken yaşlarda televizyon izlemeye ve internet teknolojilerini kullanmaya başlamakta, zamanlarının büyük bir kısmını ekranlar karşısında geçirmektedir. Dijital medya çocuklara; sanal sosyalleşmeyi, bir takım ideolojik kültürel değerleri, tüketici yaşam tarzını, şiddeti ve 
cinsiyetçi bir kültürü öğretebilmektedir. Günümüzde çocuk bireylerin internet bağımlılığı, televizyon bağımlılığı, cep telefonu bağımlılığı, oyun bağımlılı̆̆ı sorunu hayatlarının bir gerçeği haline gelmiş bulunmaktadır. Dijital medya, çocukların iletişim biçimlerini, oyun oynama ortam ve şekillerini, bilgilenme tarzlarını etkileyebilmektedir. Dijital medya araçları aynı zamanda çocukların hayal güçleri, aklını kullanma, muhakeme yapma, etkili konuşma gibi becerileri üzerinde de olumsuz etkileri olabilmektedir.

Çocuğun dijital medyayı yoğun kullanma süresi ve şekli beraberinde çocuğun kendini odasına kapatması, aile bireyleri ile az iletişim kurması, içine kapanması, asosyalleşmesi, aile bireyleriyle sohbet etmemesi, uyku ve beslenme alışkanlığının bozulması, kilo alması gibi sorunlara neden olabilmektedir. Çocuklar interneti eğitim ve araştırma amaçlı değil de, daha çok oyun ve eğlence amaçlı kullanmaktadır. Bu da beraberinde çocuğun evde derslerine çalışmaması, ödevlerini yapmaması, ders çalışmakta zorlanması, okul sınav notları ve başarısında düşüş yaşaması, kitap okumaması gibi sorunları beraberinde getirebilmektedir.

Günümüzde aile ortamlarında yapılan birçok faaliyetin yerini artık dijital medya araçlarını izleme ve tüketme almaya başlamıştır. Çetinkaya ve Sütçü'ye göre(2016, s.79), “bilişim teknolojilerindeki gelişmeler ve bu teknolojilerin kolay erişilebilir hale gelmesi, toplumsal yapıyı ve bireyler arasındaki ilişkileri şekillendirirken aynı zamanda ailede anne baba ve çocuk ilişkilerini de etkilemeye başlamıştır". Medya araçlarının başında gelen televizyon, Türkiye' de aile ilişkilerini etkileyen önemli kitle iletişim araçlarındandır. Batmaz ve Aksoy (1995), televizyonun artık bir aile bireyi olarak algılandığı ve ülkemizde evlerin "elektronik hane" haline geldiğini ifade etmektedirler.

Aile ortamında anne-baba ve çocukların televizyon, bilgisayar ve cep telefonları ekranları karşısında zaman geçirme süreleri artış göstermiş, oyun ve eğlence içeriği ile yoğrulmuş ekran dünyasının cazibesi aile bireylerini kendisine bağımlı kılmayı başarabilmiştir. Ev ortamında anne televizyon ve internette kadınlara yönelik dizi, eğlence, magazin programları ve sosyal medya araçlarıyla zaman geçirmeyi tercih ederken; baba, daha çok televizyon ve internet ekranları karşısında haber, dizi, eğlence, futbol programlarını ve sosyal medyayı tercih edebilmektedir. 
Çocuklar ise televizyonda daha çok müzik, yarışma eğlence programlarını, çizgi film, dizi filmlerin yanı sıra tablet veya cep telefonu ile internette oyun oynama veya sosyal medyada zaman geçirmeyi tercih edebilmektedir.

Uzmanlar uzun süreli televizyon izlemenin, bilgisayar ve internet kullanımının aile içi anne baba ve çocuk ilişkisini olumsuz yönde etkilediğine dikkat çekerek aile bireylerinin televizyon, bilgisayar, tablet ya da internet başında kontrolsüz zaman geçirmelerinin aile içi iletişim sorunlarına neden olabildiğinin altını çizmektedirler. Aile bireylerinin medya araçlarının ekranlarına kilitlenmeleri onların birbiriyle iletişim kurmalarını zorlaştırabilmekte, aile bağlarının körelmesine neden olabilmektedir. Birincil ilişkilerin hakim olduğu, toplumsallaşmanın ilk ve en önemli adımını oluşturan, bireyi birçok yönden koruyan ve kollayan ailede, dijital teknolojilerle birlikte bir takım değişimler meydana gelmiştir. Batıgün ve Kılıç'a göre (2011, s.2-3), "insanlar internetteki aktiviteler ile yeni bir yaşam tarzı geliştirmekte, bu durum da gerçek sosyal ilişkilerde kötüleşmesine yol açmaktadır. Başka bir deyişle depresif bireyler sosyal destek için internete bel bağlamakta, bu durum da gerçek yaşamlarındaki kişilerarası ilişkilerinin daha kötüye gitmesine neden olarak internet bağımlılığı riskini artırmaktadır". Demir'e göre (2016, s.30), "yapılan araştırmalarda, internette çok fazla zaman geçirilmesinin insanları yalnızlığa sürüklediği, bireyleri ait olduğu sosyal çevreden koparttığı, akrabalık ve arkadaşlık ilişkilerini zayıflattığı dile getirilmektedir". Hazar ise (2011), sosyal medyanın insanların ailesi ve arkadaşlarıyla yüz yüze ilişki oluşturmasını engellediğini, samimi ilişkileri azalttığını belirtmektedir.

Yapılan araştırmalara göre aşırı internet ve sosyal medya kullanımının yalnızlığa sebep olduğu ve yalnız bireylerin, interneti daha aşırı olarak kullandıkları belirtilmektedir. Kraut ve diğerleri (1998) yaptıkları araştırmada ailede internetin fazla kullanılmasının ve internet başında yoğun geçirilen zamanın aile içi iletişimi olumsuz etkilediğini, ailede sosyal bağları zayıflattığını, sosyal katılımlarında düşüşü meydana getirdiğini, kişilerde yalnızlık ve depresyon durumundaki artışları meydan getirdiği ortaya koymuştur. Demir (2016), sosyal medya ile ilgili yapılan araştırmalarda bireylerin ailesi ve yakın çevresi ile iletişimleri üzerinde olumsuz etkileri olduğunu belirtmektedir. Demire göre, "sosyal medyayı yoğun bir 
biçimde kullanan öğrencilerin aile içi konuşulan konulardan sıkıldıklarını, aileleri ile beraberken bile sosyal medyada olan olayları merak ettiklerini belirtmişlerdir. Ayrıca öğrenciler, aileleri ile zaman geçirmek yerine akşamları odalarında sosyal medyayı takip etmeyi tercih ettiklerini belirtmişlerdir" (s. 45). Demir, sosyal medyanın yoğun kullanımının ailede iletişimi ve ilişkileri etkilediğini belirtmektedir. Demir'e göre, "artık insanlar sabah uyandıklarında birbirlerine 'günaydın' demeden önce akıllı telefonları ile sosyal medya hesaplarını kontrol eder hale geldiler. Teknoloji ile birlikte dijital dünyadaki hızlı değişim ve ilerlemeler internet bağımlılığ ve iletişim sorunları günümüzde insanları yalnızlaştırmaktadır" (s.46).

Sosyal medyanın aile ilişkileri üzerinde diğer bir etkisi de evlilik ilişkileri üzerinedir. Sosyal medya kullanımı evlilik ilişkilerini olumsuz etkileyebilmekte, eşler arasındaki güvensizlik sorununu tetikleyebilmektedir. Aile ortamında bazı erkek ve kadınlar, sosyal medya aracılığıyla tanımadıkları insanlarla ilişkiler kurabilmekte, bunların bir kısmı boşanma ile sonuçlanabilmektedir. Güleç'e göre (2018, s.106), "sanal âlemin verdiği esneklik ve bilinmezliğin etkisiyle sanal flörtlerin ve sanal aldatmaların yaşanmasına zemin hazırlamasından dolayı eşler arasında güvensizlik ve huzursuzluk oluşturmaktadır".

Dijital medyanın, çocukları; fiziksel, zihinsel, psikolojik ve kültürel olarak etkilediğini söylemek mümkündür. Çocukların televizyon izleme ve internet teknolojilerini kullanma alışkanlıkları çok erken yaşlardan itibaren başlamakta, onların pek çok özelliği, ilgisi ve alışkanlıklarının şekillenmesinde dijital medya araçları aktif rol onamakttadır. Günümüz çocukları televizyon ve bilgisayarla iç içe yaşayan bir kuşaktır. Daha okuma yazmaya başlamadan medya dünyasının içerik ve kahramanlarıyla temas ederek dijital dünyanın içine dahil olmaktadırlar. İletişim teknolojilerinin gelişmesiyle beraber çocuk bireylerin internet bağımlılı̆̆ı, televizyon bağımlılığ hayatlarının bir gerçeği haline gelmiştir. Bu bağımlılıklarla birlikte çocuklar kitap okuma kültüründen, spor ve oyun kültüründen uzaklaştılar.

Uzmanlar 3 yaşına kadar çocukların televizyondan uzak tutulması gerektiğini söylemektedir. Yeşilay Genel Başkan Yardımcılığı da yapan Klinik Psikolog Mehmet Dinç, çocukların teknoloji bağımlısı olmasının en 
büyük sebeplerinden birisinin anne babaların televizyonla kurdukları sağlıksız ilişki modeli olduğunu söylemektedir. Çocukların 3 yaşına kadar mümkün olduğunca televizyondan uzak tutulması gerektiğine dikkati çeken Dinç, bunun yerine aktif oyunlarla çocuklar ile iletişim kurulmasını önermektedir. Dinç'e göre, beyin gelişiminin yüzde $70^{\prime} \mathrm{i}$, yaşamın ilk yılında tamamlanmakta, Çocuk, 0-3 yaş arasında vücut hareketleri, el becerileri, işitme, görme ve konuşma, sosyal davranış ve oyun oynama yetisi kazanmaktadır. Dil ve zeka gelişiminin çok hızlı olduğu bu dönemde uzun süreli televizyon izleyen çocuklarda gelişim geriliğinin ortaya çıkma olasılığını artırmaktadır (NTV, 2017).

Dijital medya çocukların iletişim biçimleri, oyun oynama ortamları ve şekilleri, bilgilenme tarzları üzerindeki etkili olabilmekte, dolayısıla çocukları doğadan ve gerçek toplumsal ilişkilerden koparabilmektedir. Dijital medya araçlarının içeriklerinin çocukların hayal güçlerini kullanma, aklını kullanma, muhakeme yapma, etkili konuşma gibi becerilerin geliştirilmesinde olumsuz anlamda etki edebilmektedir (Çakıral, 2016; İnal, 2015; Şirin, 2015).

Dijital oyunların, çocuk ve ergenlerde psikolojik travma, olumsuz kimlik gelişimi, kişilik bozuklukları, yalnızlaşma, yabancılaşma ve toplumsal olaylara karşı duyarsızlaşmaya neden olabildiği belirtilmektedir. Sağlık Bakanlığı tarafından Kasım 2018'de Ankara'da düzenlenen "Dijital Oyun Bağımlılığı Çalıştayı" sonuç raporuna göre, çocukları ve ergenleri oyun bağımlılığına iten faktörler şu şekilde sıralanmaktadır: Günlük hayatın problemleri, stresli yaşam olayları ve olumsuz duygulardan uzaklaşma isteği, gruba ait olma, sosyalleşme ve rekabet ihtiyacının dijital oyunlarla karşılanması, sosyal gelişimdeki yetersizlik, yaşıtlarla iletişim kuramama, içe dönüklük, yalnızlık duygusu, sosyal kaygılar, sosyal beceri yetersizlikleri, düşük benlik saygısı, çocuk ve ergene bağlı faktörler (Türkiye Gazetesi, 2017). Raporda, oyun bağımlılığı ile ilgili çocukları bekleyen tehlikeler ise şu şekilde ifade edilmiştir: Uygunsuz içeriklere maruz kalması, zararlı alışkanlıklara yönelmesi, akademik başarının düşmesi, sosyalleşememesi, aile işlevlerinin bozulması, istismara ve siber dolandırıcılığa maruz kalması, suça karışması, argo sözcük kullanımının artması, konuşma ve yazma becerilerinin bozulması, insanlarla ilişkilerinin bozulması, beslenme alışkanlıklarının bozulması, obezite gibi kronik hastalıkların ortaya çıkması, depresyon, anksiyete bozukluğu gibi 
psikolojik bozukluklar yaşaması, dijital oyunlarda para kazanılması nedeniyle eğitime devam etmeye gerek görmemesi, bahis oyunlarına yönelmesi, kumar alışkanlığı edinmesi (Türkiye Gazetesi, 2017).

Çocuklar iletişim araçlarını kullanırken yeterli deneyim, bilgi ve donanıma sahip olmadıklarından, bu içerikler karşısında savunmasız bir pozisyondadır. Dijital medya araçları çok önemli bir etki yaratmasına karşın, çocuk bireyler medyanın işleyişi ve gücü konusunda bilinçli bir eğitim seviyesinde değildirler. Bu anlamda anne ve babaların, çocuğun dijital medyayı kullanım şeklinden ve ilişki kurma biçiminden kaygılı olduğunu söylemek mümkündür. Çocuğun dijital teknolojileri kullanma süresinin uzun olmasından kaynaklı çocuğun kendisini odasına kapatması, aile bireyleri ile az iletişim kurması, konuşmaması, içine kapanması, asosyalleşmesi, sohbet etmemesi, çocuğun uyku ve beslenme alışkanlı̆̆ının bozulması, bilgisayar karşısında aperatif fast food tarzı beslenme ile kilo alması, hareketsiz yaşam sürmesi gibi sorunlar ailelerin çocuklarla ilgili kaygıları arasındadır.

Çocukların interneti araştırma amaçlı değil de, daha çok oyun ve eğlence amaçlı kullanması, çocuğun eğitim hayatına yansıyabilmekte çocuğun evde derslerine çalışmaması, ödevlerini yapmaması, ders çalışmakta zorlanması, okul sınav notlarında ve başarısında düşüşs, kitap okumama eğilimini de beraberinde getirebilmektedir. Çetinkaya ve Sütçü (2016), ebeveynlerin çocukların bilişim teknolojileri ile yoğun geçirdikleri zamandan dolayı eğitim-öğretim faaliyetlerinin, aile içi görev ve ilişkilerin, sosyal hayatlarının olumsuz etkilendiği ve sağlıklarının olumsuz etkilendiği düşüncesiyle çocuklarının dijital medya kullanımlarına kısıtlama getirmeye çalıştıklarını ifade etmektedirler. Çetinkaya ve Sütçü'ye göre (2016, s.83), "ailelerin, çocuklarının teknoloji ve uygulamalarını kullanımlarına yönelik ilgi ve endişeleri de artmıştır. Çünkü çocuklar ilk dijital nesil olarak yeni iletişim teknolojilerinin öncüleridir. Ancak aynı zamanda onların beraberinde getirdiği risklere de açıktırlar". Ebeveynler medya ve iletişim araçlarının çeşitliliği ve giderek artan karmaşıklıkları konusunda önemli zorluklarla karşılaşmaktadırlar. İnternetin giderek yaygınlaşması ve gençlerin erişimine açı bol miktardaki içerik, ebeveynleri ciddi endişelendirmektedir (Çetinkaya ve Sütçü, 2016). 
Çocuklar neredeyse cep telefonu, tablet ve bilgisayarla yapışık halde onlarsız yaşayamaz hale geldiler. Çocukların cep telefonu tabletler ve bilgisayar kullanma süreleri konusunda ailelerle çatışma ve pazarlıklar yaşanabilmektedir. Kimi aileler çocuklarının okul ödevlerini, projelerini yapmaları için internetin bilgi erişiminden yararlanmalarını sağlamak amacıyla, "arkadaşlarında var onun da olsun", düşüncesiyle ya da evde oyalansın, sıkılmasın diye cep telefonu ya da tablet almışlardır. Ama daha sonra hem kendisi hem de çocuk bu araçların kullanımı konusunda fazla bir bilgi sahibi olmadığından sonraki süreçte pişmanlık duyabilmektedirler. Cep telefonu ya da tablet alındıktan sonra çocuk, kendisini internette sanal oyunlara, videolara kaptırabilmekte, sosyal medyada sürekli arkadaşlarıyla mesajlaşmakta, müzik dinlemekte ve aile bireyleriyle artık iletişimi kopabilmektedir.

\section{Dijital Medya Okuryazarlı̆̆ııın Anne ve Babaya Să̆layacağı Katkılar}

Dijital medya okuryazarı bir anne ve babanın aile ilişkilerine önemli bir katkı sağlayacağını söylemek mümkündür. Dijital medya okuryazarlığı konusunda eğitim alan bir anne ve baba öncelikle aile üyelerinin dijital medya araçlarını yoğun kullanımdan kaynaklı ilişkilerinde yaşanan sorunları düzenleme, kontrol altına alma, sorunları yönetebilme becerisi kazanabilecektir. Dijital medya okuryazarlığı aile bireylerinin birbiriyle yeniden yüz yüze iletişim kurmalarına işlerlik kazandıracak, körelen aile bağlarının güçlendirilmesine, şefkat ve ilginin yeniden gelişmesine olanak tanıyabilecektir. Anne babaların alacağı dijital medya okuryazarlığı eğitimi ile aile bireyleri televizyon izleme, sosyal medya kullanma, internete girme sürelerinde azalma medyana gelebilecek ve kişi ailesine ve arkadaşlarına daha çok zaman ayırabilecektir.

Sağlıklı bir toplumun temel gereksinimi olan sağlıklı iletişimin yolu, toplumun çekirdeği olarak kabul edilen ailedeki iletişimin sağlıklı olmasıyla temellendirilmektedir. Aile üyelerinin arasındaki iletişim de ailenin sağlığ ile ilişkilidir. Birbirleriyle az konuşan, açık iletişim içinde olmayan ve birbirlerine karşı samimi yakınlık duyamayan bireylerden oluşan aile sağlıklı görünmemektedir (Güleç, 2018). Bu anlamda günümüzde aile içi sağlıklı bir iletişimin kurulması dijital medya ko- 
nusunda ebeveynlerin alacağı eğitim ile desteklenebilecektir. Aile üyelerinin kendilerine ve diğer aile üyelerine ayırdıkları zamanın artışıyla birlikte aile içi iletişim güçlenebilecektir. Ebeveynlerin birbirlerine ve çocuklarına karşı daha fazla ilgi göstermelerine ve aile bireylerinin birbiriyle sağlıklı iletişim kurmalarına katkı sağlayacaktır.

Dijital medya okuryazarı bir anne ve babanın çocuğun zihinsel, bilişsel, duygusal gelişimine katkısı olacaktır. Bu anne ve babalar, çocukların dijital medya araçlarını seçme, kullanma, eleştirme, olumsuz içerikten korunma bilinci geliştirmelerine, çocukların okul döneminde alacakları medya okuryazarlığı dersinde daha istekli ve başarılı olmalarına katkı sağlayacaktır.

Çocukların dijital medya araçlarını artan oranlarda kullanmaya başlaması ile paralel bir durum da çocuklara dijital medyayı nasıl doğru kullanmaları gerektiği ve medya içeriklerine karşı nasıl eleştirel bir tutum takınmaları gerektiğine yönelik çabaların her geçen gün öneminin artmasıdır. Dijital medya okuryazarlığı eğitiminde ev ve okul iki ayrı kaynak kurum olarak ön plandadır. Çocuklara dijital medya okuryazarlığı bilincinin kazandırılmasında okulda öğretmenler evde ise ebeveynler önemli rol oynar. Gül'e göre (2007, s. 22), “okullar çocukların ailelerinden ve toplumdan ayrışmış olarak hizmet veremez. Okullar, çocukların eğitiminde aile katılımının sağladığ 1 katkılardan yararlanmak durumundadır. Çocuklarının okuldaki eğitimlerine katılan ebeveynler aynı zamanda, çocuklarının eğitiminde önemli derecede söz hakkına sahip olan ebeveynlerdir". "Ailelerin çocuklarının sosyal, fiziksel ve akademik gelişimlerinde yer alma hakları ve gereksinimleri vardır. Yapılan birçok araştırmada da, evde ve okulda aktif aile katılımının yararları ortaya koyulmuştur. Aileler, çocuklarına okuryazarlık için model olarak, evdeki günlük deneyimleri içerecek şekilde, sözel ve yazılı dili öğrenmeleri için fırsatlar sunarak çocuklarının okuryazarlık sürecine katkı sağlamaktadırlar" (Gül, 2007, s.25).

Dijital medya okuryazarlığı eğitimi erken çocukluk döneminden itibaren başlanması gereken bir süreçtir ve bu süreçte ebeveynlerin okuryazarlık konusunda beceri kazanmış olması önemlidir. Televizyon, internet ve cep telefonu kullanma sosyal medya kullanma, online oyun oynama alışkanlıkları ilk çocukluk döneminde aile tarafından verilecek eğitim ile düzenlenebilir. Çocukların bu araçları izleme süreleri, programlarda 
seçici olma becerisi, gördüğü kişileri taklit etme düzeyleri, ailenin erken dönemlerde vereceği eğitim ile kontrol altına alınabilir. Aynı zamanda çocukların okuldaki eğitim süreçlerinde alacağı medya okuryazarlık eğitimini de kolaylaştırmasını ve öğrencinin bu alanda başarılı olmasını sağlayabilir. Gül de (2007) ailelerin erken dönemden itibaren okuryazarlık sürecinde etkin rol oynamalarının önemli bir sorumluluk olduğunu hatırlatmaktadır. Gül okulöncesi dönemden itibaren, erken okuryazarlığın önemini vurgulayarak erken dönemdeki kazanımlara dikkat çekmektedir. "Çocuklar için en yakın ve güvenilir bilgi kaynakları olan aileler, aynı zamanda bebeklik döneminden itibaren tutumların şekillenmesinde etkili olan modellerdir. Dolayısıyla, ebeveynin okuryazarlık deneyimleri ve tutumları, çocuklara sunulan fırsatlar ve çocukların okuryazarlığa yönelik bakış açıları üzerinde de etkili olmaktadır" (Gül, 2007, s.27).

Anne ve babaların erken yaşlardan itibaren çocuklara dijital medya okuryazarlığı konusunda verimli ve başarılı bir rol model olabilmeleri için konuyla ilgili bir eğitim almaları bir gerekliliktir. Çocuklara medya okuryazarlığı bilincinin kazandırılmasında ebeveynlerin yeterli bir eğitim seviyesinde olmaları önem arz etmektedir. Çocukların dijital medya araçlarını doğru kullanması ve medyanın olumsuz etkilerinden korunması ve bilinçli birer medya tüketicileri haline gelebilmeleri, öncelikle dijital medya konusunda okuryazar bir anne babanın varlığından geçmektedir. Ebeveynlerin teknolojik ürünleri çocuklarının hayatına hiç sokmayarak ya da yasaklar getirerek olumsuz etkilerinden korumaları mümkün gözükmemektedir. Bu noktada ebeveynler, teknolojinin çocukları üzerindeki olumlu ve olumsuz sonuçlarını dengelemek için sürekli bir mücadele halindedirler. Çetinkaya ve Sütçü'ye göre (2016, s. 84), “ailelerin çocuklarını olumsuzluklardan korumak amacıyla tutundukları tavırları bazen daha büyük olumsuzluklar yaşamalarına neden olabilmektedir. Ailelerin, dijital teknolojilerle çevrili olarak büyüyen çocuklarına karşı tutumları ve bu tutumlarının çocuklar tarafından nasıl algılandığı oldukça önemlidir". Anne-babanın dijital medya konusunda eğitim almaları çocuklarının davranışlarına kaynaklık eden medyayı daha iyi anlayarak çocuğa nasıl daha doğru yaklaşması, tutum sergilemesi gerektiği noktasında yardımcı olacaktır. 
Dijital medya okuryazarlığı konusunda eğitim almayıp bilinç geliştirmeyen anne ve babaların çocukları bağımlı olma riski ve her türlü etkiye açık olma durumu ile karşı karşıyadırlar. Ebeveynler tarafından bilinçsiz bir şekilde televizyon karşısına bırakılan çocukların bu araçlardan daha fazla etkilenmesi kaçınılmaz hale gelebilmektedir. Kitle iletişim araçları konusunda tam anlamıyla bilgi sahibi olmayan ebeveynlerin, çocuklarını dijital medyanın olumsuz öğelerinden koruması zor görünmektedir. Çakıral'a göre (2016, s.22), “ailelerin çocukların temel eğitimleri konusunda yetersiz olmaları, yeterince ilgilenmemeleri, çocukların eğitimlerini konusunda büyük bir boşluğu karşımıza çıkarmaktadır. Bu boşluğu sosyalleşme ve eğlenme bağlamında televizyon doldurmaktadır". Daha da ileri giderek televizyon veya bilgisayar ekranları aracılı̆̆ıyla çocuklarına yemek yediren anne babalar, bu teknolojileri bir oyuncak olarak gömebilmekte ya da çocuklarının bakıcısıymış gibi davranabilmektedirler. Şirin'e göre (2015, s.14), "ailede çocuğa gösterilen ilgi azsa, televizyon çocuk için dadı rolünü yerine getirmeye başlar". Pek çok yerde evde, kafede, otobüste, alışveriş merkezlerinde vb. yerlerde çocukların ellerine mobil telefonlarını ya da tablet bilgisayarları vererek oyalayan anne babaları görebilmek mümkündür. Çocuklar saatlerce ekran başında gömülü bir şekilde sosyal hayattan koparak çevrelerindeki her şeyden ve herkesten uzaklaşabilmektedir. Bu durum ilerledikçe anne ve babayı da rahatsız etmeye başlamakta ama iş işten geçmekte ve çocuk bir bağımlılık sürecine girilebilmektedir. Bu bağımlılık süreci, bu durum karşısında ne yapması gerektiğini bilmeyen anne baba ve çocuk arasında çatışma üretebilmektedir.

Dijital medya okuryazarı anne baba, çocuklara internet ve televizyon ortamlarında üretilen içerikleri doğru bir şekilde algılamalarında, bu içeriklerden zarar görmemelerine ve kurguyla gerçeğin farkına varmalarına yardımcı olabilir. Bu okuryazarlığın çocukta dil gelişimine de olumlu katkıları olabilir. "Ebeveynler çocuklarının ilk dil öğretmenleridirler. Anlamlı iletişim fırsatları sunan her durumda aile üyeleri ile konuşarak ve etkileşimde bulunarak ebeveynler çocuklarına model olurlar. Hareketleri ve tepkileriyle ebeveynler çocuklarının dil kodlarını çözmelerine ve var olan bir durumda uygun şekilde nasıl konuşulacağını öğrenmelerine yardım ederler. Ailenin destekçilik rolü, ailenin çocuğun öğrenmesini teşvik edici bir ev yaşantısı oluşturabilmesi, çocuğun başarısı ve 
gelecekteki performansı hakkında daha yüksek, ancak makul beklentiler oluşturması ve çocuğun evdeki, okuldaki ve toplumsal yaşamdaki eğitimine katılması anlamına gelmektedir" (Gül, 2007, s.22).

Çocuklar zaman zaman gerçek ile kurguyu ayırt etmede bir takım zorluklar yaşayabilmektedirler. Çocukların televizyon, tablet, bilgisayar, cep telefonu gibi dijital medya araçlarını bilinçli ve etkili bir biçimde kullanmayı öğrenmeleri, kurguyla gerçeğin farkına varmaları dijital medya okuryazarlığı konusunda onlara rehber olabilecek bilinçli anne baba ile olanaklıdır. Çocuğa ilk eğitim aile ortamında anne ve baba tarafından verilmektedir. Bu bağlamda anne ve babaların çocuğa karşı önemli sorumlulukları olduğunu bilmek gerekir. Özellikle dijital medya konusunda ailenin çocuğu rehber olarak koruması, yönlendirmesi, bilgi vermesi çocuğun bireysel gelişimi açısından büyük önem arz etmektedir. Çocukların dijitalleşen ve değişen bir dünyaya uyum sağlayabilmeleri, medyanın içeriklerinden zarar görmemeleri, sağlıklı bir gelişim göstermeleri ailenin dijital medya okuryazarı eğitimi alması ve erken dönemden başlayarak çocuğa vereceği destek ile mümkün hale gelebilecektir.

Çocukların dijital medya kullanımları konusunda anne-baba eğitiminin önemi gün geçtikçe artmakta, çocukların erken yaşlardan itibaren görülen medya kullanımlarının bağımlılığa dönüşmemesi, çocukların iletişim teknolojilerine karşı daha sağlıklı bir ilişki ve tutum geliştirmelerinde öncelikle ailelerin eğitilmesinin gerekliliği görülmektedir. Şirine'e göre (2015) çocukların medya okuryazarlığı konusunda ilk alışkanlı̆̆ı ailede başlar. "Çocukların medya kullanma ve tüketme alışkanlıkları aileden bağımsız ele alınamaz" (s.23). "Çocuğa programın hangi amaç için izleyeceğini, tüketeceğini öğretmezseniz çocuğun medya bağımlısı olması kaçınılmazdır" (s.14). Çocuğun medyayı ne kadar kullanacağı medya eğitiminin önemli bir boyutunu oluşturur. Çocukların medyayı kullanma amaçları ve süresi anne ve babanın çocuğa yönelik tutumu dijital okuryazarlık ile ilişkili bir konudur. Çocuklarının medya kullanım amaç ve sürelerini düzenlemeyi başaramayan ebeveynlerin çocuklarının duygusal, zihinsel ve sosyal gelişimleri risk altındadır. Çocuğun kişiliğinin gelişmesi, ihtiyacı olan yaşamsal bilgileri edinmesi, toplumsal çevresi hakkında sağlıklı bilgi sahibi olması, doğal bir biçimde sosyalleşmesi, ruhsal, duygusal, sosyal ihtiyaçları için gerekli olan bilgiyi 
ve beceriyi kazanması anne babaların dijital medya okuryazarı kapsamındaki hedefler arasındadır.

Yurdakul vd. göre (2013, s.890), dijital okuryazar ebeveynlerin, dijital olanakların olumsuz yönlerinin farkında olmaları için "çevrimiçi ortamlardaki olumsuzlukları fark etme, çevrimiçi ortamlardaki risklerin farkında olma, internet bağımlılığını fark etme, tehlike sinyallerini fark etme, çocuğun bilgisayarda ya da internet'te ne yaptığını ayırt etme" özelliklerine sahip olmaları gerektiğine vurgu yapmaktadır. Yurdakul vd. göre (2013), dijital okuryazar ebeveynler kontrol aşamasında ise "çocuklarını uçsuz bucaksız bir ortamda yalnız bırakmama, filtre programları gibi yazılımları kullanma, çocuğun ne zaman ve ne kadar internet ya da bilgisayar kullanabileceğine yönelik kılavuz hazırlama" (s.892) gibi özellikleri taşımalıdır.

Ebeveynlerin dijital medya okuryazarlığı eğitimi konusunda önemli eksiklikleri bulunduğunu söylemek mümkündür. Roberts, Foehr ve Rideout (2005), günümüz çocuklarının bir medya dünyasında yaşadıklarını ve 8-18 yaşları arasındaki gençlerin günün 6,5 saatini okul dışında medya araçları ile meşgul olarak geçirdiklerini söylemektedirler. Aileler 8-18 yaş arası çocuklarıyla günde yaklaşık 2,5 saat beraber vakit geçirmekte, çocukların medya kullanımları ile ilgili farklı yaklaşımlar benimseyebilmekte kimisi katı kurallar koyarken kimisinin ise bunu önemsemediğini söylemektedir. Browne (1999) ise, gençlerin çoğunun ebeveynleriyle beraber geçirdiği sürecin çoğunlukla televizyon ve video izleme ile geçtiğini söylemektedir. Ailenin, bu anlamda, dijital medya okuryazarlı̆̆ 1 eğitimi eksikliğine vurgu yapmaya çalışılmaktadır.

Aytaş ve Kaplan'a göre de (2017, s.305) aileler internet hakkında gereken bilgi düzeyine sahip değildir. "Çocuklardan önce anne ve babaların internet konusunda kendilerini geliştirmeleri ve bu teknolojiyi sağlıklı bir şekilde kullanmayı öğrenmeleri gerekmektedir. Ailelere medyadan ziyade internet okuryazarlığı bilincinin aşılanması birincil derecede önemlidir. İnternet okuryazarlığının gelişim gösterebilmesi adına doğru devlet politikalarının izlenmesi, gerekli medya desteğinin sağlanması ve internet okuryazarlığına önem verilmesi gerekmektedir". RTÜK (2016), ebeveynlerin dijital medya okuryazarı olması ya da bu eğitimin öneminin bilincinde olmasının çocukların okullarda edindikleri medya 
farkındalığını yükselteceğini belirtmektedir. Ancak dijital medya okuryazarlı̆̆1 ve ebeveynlerin buradaki rolü anlamında bazı sorunlar bulunduğunu, dijital nesille dijital dünyaya sonradan katılanlar arasında bilgi ve beceri uçurumu olduğunu dolayısıyla ebeveynlerin dijital teknolojilerin kullanımıyla ilgili çocuklarına bilgi ve beceri verecek düzeyde olmadıklarını ifade edilmektedir. Bu anlamda ebeveynlerin dijital dünya hakkında sahip oldukları bilginin çok yetersiz olduğu ve onları eğitme ve bilgilendirme konusunda bir boşluk bulunduğunu söylememiz mümkündür.

Dijital medya okuryazarlığı eğitimi almış anne babalar, çocukların dijital medya araçlarını kullanım sürelerini düzenleyerek, model olarak, doğru diyalog ve tutum takınarak, koruyucu programlar kullanarak çocukların bu becerilerinin gelişimine katkı sağlayabilirler. "Yapılan araştırmalarda, bireyler arası sınırların iyi tanımlanmış ve iletişimin yüksek olduğu ailelerdeki çocukların sorunlarını daha rahat çözdüğünü ve okul başarısının daha yüksek olduğunu ortaya koymaktadır" (Özgüven, 2011, s.34). Dijital medya kullanma ve tüketme alışkanlığını çocuk ilk olarak aile ortamında öğrenir. Anne ve babanın hayata bakışı, yaşam tarzı çocukların sergiledikleri tavırlara da yansıyabilmektedir. Anne ve baba televizyon izleme ve internet kullanma konusunda çocuğa örnek olarak kullanım süresini kısaltabilmelidir. Zaman içerisinde elindeki cep telefonuyla ya da başka bir sosyal medya aracıyla yoğun bir şekilde meşgul olan bir anne-baba görmeye başlayan çocuğun, ileriki süreçte aynı tavırları sergilemesi kaçınılmazdır. Ölçüsüzce sosyal medyada zaman geçiren, televizyon izleyen anne-baba, ileride çocuktan bunu yapmamasını beklememelidir. Çünkü çocuk ve aile etkileşiminde önemli olan anne ve babanın davranışlarıdır. Anne ve babanın davranışlarını örnek alan çocuk, hayatını onlardan gördüğü ve öğrendiği hareketlere, tutum ve davranışlara göre şekillendirmektedir (Demiriz ve Öğretir, 2007).

Okuryazarlık konusunda bilinçlenmiş anne ve baba evde çocuğu televizyon ve internet ekranı karşısına mahkûm etmeyerek, çocuğun bu teknolojileri kullanmasına sınırlama getirerek, interneti beraber kullanarak, televizyonu beraber izleyerek, izlenen programlar hakkında çocukla konuşarak bir gelişim kaydedebilir. Livingstone ve Haddon (2009), anne ve babaların çocuklarına internet ortamlarında gezinirken rehber olmaları durumunda çocukların karşılaşabildikleri riskleri azalttığını 
ifade etmişlerdir. Anne ve babaların internet kullanımlarında rehberlik etmesi, internetteki içerik ve materyaller hakkında konuşmasının çocuğu mutlu ettiğini ve cesaretlendirdiğini söylemektedirler. Okuryazarlık konusunda bilinçlenmiş ailelerin çocuklarını internetin zararlı içeriklerinden koruma amacıyla çocukların internette geçirdiği zamanı en iyi şekilde değerlendirmelerine rehberlik edebileceklerini, çocukların ekran karşısında geçirdikleri zamanla ilgili olarak ılımlı bir yaklaşım sergileyebileceklerini, çocukların internette ne kadar zaman geçirdiğinden ziyade ne yaptığına odaklanabilmeleri gerektiğine dikkat çekmeye çalışılmaktadır (UNICEF, 2017). Tan (2015), ailelerin çocuklarını medya içeriklerine karşı yasaklayıcı bir yaklaşım benimsemeleri yerine, düşüncelerin özgürce dile getirilebildiği bir tartı̧̧ma ortamı yaratarak, çocuğun medya içerikleri bağlamında eleştirel tavır geliştirmesine yardımcı olacağını belirtir. Bu bağlamda anne-babanın, çocuğun maruz kaldığı ve onu rahatsız eden imgeler hakkında konuşup tartışılabilen güvenli bir aile ortamı yaratabilmeleri önem arz etmektedir.

Dijital okuryazar bir anne-babanın çocuğu televizyon izleme ve internette yoğun zaman geçirme faaliyetine karşı başvurabileceği yöntemlerden biri de; çocuğu gezi, spor, sanat, tiyatro, yarışma, ekran dışı oyun vb. faaliyetlere teşvik ederek yönlendirebilmesidir. Anne ve babalar zaman zaman televizyonu kapatarak çocuklarına örnek olabilecek beraber kitap okuma, müzik dinleme ya da oyun oynama konusunda uğraş vererek model olabilir. Özellikle ekran dışı oyunların çocuğun fiziksel ve bilişsel gelişimi açısından önemi büyüktür. Çocuk, ekran dışı oyunları oynayarak beş duyuya dayalı çok yönlü ilişki kurmayı öğrenerek, yaptıkları karşılığında yanıt alarak ve duyguya duygu ile karşılık vererek fiziksel ve bilişsel gelişim sağlar. Ancak ekrana dayalı bilgisayar oyunlarında çocuk söz konusu hareket ve becerilerden yoksundur. Ekrana dayalı bilgisayar oyunları çocuğun dil yeteneğini bozarak geç konuşma olasılığını da yükseltir.

Ebeveynler, çocuklarla sürekli diyalog kurarak, internet ortamlarında hangi sitelere girdiğinden haberdar olarak, aracılık ederek, koruyucu programlar kullanılarak çocuğun faaliyetlerine rehber olabilmelidir. Warren (2001), anne ve babaların çocukların tükettiği medya içeriklerini kontrol etme, seçme, denetleme amacıyla aracilık edebileceğini belirtmiştir. Çakıral da (2016), çocuklara rehber olma konusunda anne baba rolüne 
vurgu yaparak anne babaların televizyonu kapatma konusunda çocuklara iyi örnek olması gerektiğini, mümkün olduğu kadar programlar çocuklarla beraber seyredilmesi gerektiğini ifade eder. Ona göre, anne ve babalar televizyonu çocuğun oyalanacağı bir araç olarak görmemeli, çocuğa yemek yedirmek için bir araç olarak kullanmamalı, yemek yerken televizyon açık tutulmamalı, televizyona bakıcılık rolü vermemelidir.

Dijital medya okuryazarlığı eğitimi almış bir anne-baba çocuğu internet ortamındaki bilgi kirliliği konusunda aydınlatabilmeli, internette dolaşan pek çok bilginin güvenilir olmadığı konusunda bilgilendirmelidir. Anne ve babalar çocuğa internet ortamlarında yaralanabileceği doğru bilimsel bilgi kanallarına yönlendirme konusunda rehber olabilmelidir. Çocuklara internet ortamındaki risklerden bahsederek kişisel bilgilerini kimseyle paylaşmaması gerektiği anlatılmalıdır. Çocuklar sanal medyadaki arkadaşlıklardan ziyade gerçek hayattaki arkadaşlıklara yönlendirilmeli ve teşvik etmelidir.

Anne babalar çocuğun bilinçli ve eleştirebilen bir kişi olmasına yardım etmek, gerçek ile kurguyu birbirinden ayırt edebilmelerini sağlamak için dizi ve filmlerdeki sahnelerin gerçek olmadığı, rol gereği olduğu açıklayabilmelidir. Bunun için de Serhatlığlu'na göre (2006), anne-babaların televizyonu bilinçli kullanabileceği, çocuklarını doğru yönlendirebileceği bir dijital eğitime sahip olmaları gereklidir. Ebeveynlerin bu konuda bilinçlendirilmesi için çeşitli seminerler düzenlenebilir, televizyon programları düzenlenebilir. Ona göre aileler çocuklarıyla birlikte televizyon seyrederek neyin yanlış, neyin doğru olduğu hakkında çocuklarıyla konuşmalı ve çocuklarını televizyon karşısında yalnız bırakmamalıdır. Dijital ve medya okuryazarlığı becerileri, çoğu insanın televizyon ve film izlediği, internette gezindiği, müzik dinlediği, gazete ve dergileri okuduğu ve bilgisayar oyunları oynadığı ev ortamlarında geliştirilebilir. Bunun yanı sıra dijital medya okuryazarlık eğitimi anne ve babalara özel veya kamusal ortamlarda uzman ya da kamu spotu şeklinde hazırlanmış videolarla verilebilir. Dijital medya okuryazarlı̆̆ı becerileri aile ortamında, okullarda, yaz eğitim kamplarında, üniversitelerde ve sivil toplum kuruluşları gibi yerlerde eğitim süreci gerçekleştirilebilir. 


\section{Sonuç}

Günümüzde çocukların fiziksel, ruhsal ve düşünsel anlamda sağlıklı bir birey olarak yetişebilmesi, medyayı daha sınırlı, bilinçli, yararlı ve bilimsel amaçlar için kullanmasını öğrenmesi, dijital medyanın olumsuz etkilerinden minimum düzeyde etkilenmesi, çocuklara en yakın olan anne ve babaların bilinçli dijital medya okuryazarı olmaları ve çocuklara sağlayacakları katkı ile mümkün hale gelebilecektir. Anne ve babaların dijital medya okuryazarlığı becerilerinin yeterince gelişmemiş olması ve anne ve babaların bu konudaki eğitimine ilişkin çalışmaların yeterince yapılmamış olması, çocukların dijital medya okuryazarlığı bilinci geliştirmeleri önünde önemli bir engeldir.

Son yıllarda yapılan araştırmalarda dijital medya araçlarının yoğun kullanılmaya başlanmasıyla birlikte aile ilişkilerinde olumsuz anlamda bir değişim meydana geldiği ortaya konulmuştur. Aile bireylerinin ev ortamında çoğunlukla cep telefonu, televizyon ve bilgisayar ekranları karşısında medya içeriklerini tüketerek sürekli ve yoğun bir zaman geçirmeleri, onların birbirine ayırdıkları zamanı azaltmış, iletişimlerini, aile içi şefkat ve ilgiyi, yüz yüze samimi ilişkileri zayıflatmış, yalnızlık, depresyon, boşanma gibi bir dizi sorunu beraberinde getirmiştir (Batıgün ve K1lıç 2011; Çetinkaya ve Sütçü, 2016; Demir, 2016; Kraut ve diğerleri, 1998;). Dijital medyanın aile ilişkileri üzerindeki etkilerinin yanında ailede çocuğun fiziksel, ruhsal ve zihinsel gelişimi üzerinde de önemli etkileri olduğu ortaya konulmuştur (Çakıral, 2016; İnal, 2015; Şirin, 2015). Çocukların televizyon izleme ve internet teknolojilerini kullanma alışkanlıkları çok erken yaşlarda başlamakta ve zamanlarının büyük bir kısmını bu ekranlar karşısında geçirmektedir. Dijital medya çocuklara sanal sosyalleşmeyi, bir takım ideolojik kültürel değerleri, tüketici yaşam tarzını, şiddet ve cinsiyetçi bir kültürü öğretebilmektedir. Dijital medya çocukların iletişim biçimlerini, oyun oynama ortam ve şekillerini, bilgilenme tarzlarını etkileyebilirken aynı zamanda onların hayal güçleri, muhakeme yapma ve etkili konuşma gibi becerileri üzerinde olumsuz etkileri olabilmektedir (Akçalı, 2015; İnal, 2015; Öztürk, 1999).

Ailede anne ve babalar çocuğun dijital medyayı kullanım süre ve şeklinden kaygılıdırlar. Çocuğun kendisini odasına kapatması, aile birey- 
leri ile az iletişim kurması, içine kapanması, asosyalleşmesi, sohbet etmemesi, uyku ve beslenme alışkanlığının bozulması, kilo alması, hareketsiz yaşam gibi konular ailelerin medya tüketimi konusundaki kaygıların bir kısmını oluşturmaktadır. Çocuklar interneti araştırma amaçlı değil de, daha çok oyun ve eğlence amaçlı kullanmaktadırlar. Yoğun bir dijital medya kullanımı çocuğun evde derslerine çalışmaması, ödevlerini yapmaması, ders çalışmakta zorlanması, okul sınav notları ve başarısında düşüş, kitap okumamasını gibi sorunları beraberinde getirebilmektedir.

Dijital medya okuryazarlığı; bilgisayar, tablet, akıllı cep telefonu gibi araçlarla internet ortamlarındaki her türlü yazılı ve görsel materyal ve içeriği anlama, çözümleme, analiz etme, sorgulama, değerlendirme, bu içerikleri doğru okuyabilme ve görebilmeyi içeren bir beceri kazanma sürecidir. Dijital medya okuryazarlığı konusunda anne ve babanın eğitim alması öncelikle dijital teknoloji kullanımından kaynaklı aile ilişkilerinde yaşanan sorunları düzenleme, kontrol altına alma, sorunları yönetebilme becerisi kazandıracaktır. Okuryazarlık eğitiminin anne-babaya diğer bir katkısı da çocukların dijital medyayı seçme, kullanma, eleştirme, korunma bilinci geliştirmelerine destek olabilme fırsatını sunmasıdır. Ev destekli medya okuryazarlığı çocukların okul döneminde alacakları medya okuryazarlığı dersinde de daha istekli ve daha başarılı olmalarına imkân sunacaktır.

Çocukların televizyon izleme, internet ve cep telefonu kullanma, sosyal medya kullanma, çevrimiçi oyun oynama alışkanlıkları aile tarafından verilecek eğitim ile düzenlenebilir. Bu araçları izleme süreleri, programlarda seçici olma becerisi, gördüğü kişileri taklit etme düzeyleri, ailenin alacağı dijital okuryazarlık eğitimi ile çocuğun sonraki süreçlerde evde ve okulda devam edecek olan okuryazarlık eğitimine önemli bir temel oluşturacaktır.

Anne ve babaların dijital medya okuryazarlığı konusunda başarılı bir rol model olabilmeleri, konuyla ilgili eğitim almaları önemli bir gereklilik olarak karşımıza çıkmaktadır. Dijital medya okuryazarlığı konusunda eğitim almayıp bilinç geliştirmeyen anne ve babaların çocukları, dijital medya araçlarına bağımlı olma riski ve her türlü olumsuz etkiye açık olma durumu ile karşı karşıya kalabilirler. Ailede anne, baba ve çocuk arasında sağlıklı iletişim ortamının kurulması ve çocuğun kişiliğinin olumlu bir 
şekilde gelişmesi, anne-babaların dijital medya okuryazarı olmasından olumlu bir biçimde etkilenmektedir. Anne ve babalar dijital medya okuryazarlığı konusunda alacakları eğitim ile çocukların dijital araçları kullanım sürelerini düzenleyebilecek, internet ve televizyon ortamlarındaki üretilen içerikleri doğru bir şekilde algılamalarına, bu içeriklerden korunmalarına, dil gelişimlerine, kurguyla gerçeğin farkına varmalarına katkı sağlayacaktır. Dijital medya kullanım amaç ve sürelerini düzenlemeyi başaramayan anne babaların çocukları duygusal, zihinsel ve sosyal gelişimleri yoğun medya tüketimnden olumsuz bir biçimde etkilenebilmektedir.

Çocuklara rehber olacak ve dijital medya araçlarını kullanımını sınırlayacak bir yetişkine ihtiyaç olduğu açıktır. Çocuk ve gençlerin dijital medya konusundaki temel sorumluluk, ilk olarak eğitimlerinin başladığ yer olan aileye düşmektedir. Ancak çocukların medya okuryazarlığı becerilerinin gelişmesinde dolaylı veya direk rol oynayacak ebeveynlerin eğitimlerinin yetersiz olduğu belirtilmektedir (İnan, 2013). İnan (2013, s.2), "çocukların kitle iletişim araçlarından nasıl ve ne oranda etkilendiği, çocukların bakış açısıyla ebeveynlerinin tutumlarının nasıl olduğu, ebeveynlerin çocuklarının kitle iletişim araçlarını kullanmaları nedeniyle karşılaştıkları sorunlar hakkındaki düşüncelerinin ne olduğu ev ve okul eksenli hazırlanacak müdahale planlarına temel oluşturabileceğini" ifade etmektedir. Güneş (2013) ise, çocuğun ruh sağlığının korunması çerçevesinde sivil toplum örgütleri ve medya kuruluşlarının da dijital medya okuryazarlığı konusunu gündemlerine almaları gerektiğini söylemektedir. Alan ile ilgili yapılan çalışmaları değerlendirdiğimizde Türkiye'de dijital medya okuryazarlığı konusunda anne ve babaların önemli eksikleri bulunduğu, dijital dünya hakkında sahip oldukları bilginin çok yetersiz olduğu ve bu konuda bir boşluğun olduğu ortaya çıkmaktadır. Konuya aynı zamanda devlet organları tarafından da önem verilmesi ve bu alanda yapılan çalışmalara destek verilmesi, sosyal devlet anlayışının da bir gereğidir. Türkiye'de dijital medya okuryazarlığı konusunda ailelerin konuya ilgilerini çekerek, çocukların medya aktivitelerini anlamaları sağlanmalıdır Çocukların dijital medya okuryazarlığ1 eğitimi meselesinin daha çok bir çocuk ve aile ilişkisi meselesi olduğunun altını çizmek gerekir. 


\title{
EXTENDED ABSTRACT
}

\section{Parent Education in Digital Media Literacy}

\author{
Mehmet Tahir Karaboğa \\ Mersin Üniversitesi
}

We live in an age where digital media such as computers, mobile phones and the internet are used extensively. With the development and spread of these media means, social relations, individual life and especially family relations have been transformed. The effects of computer-based digital media have become more and more prominent. The fact that parents and children can access to an unlimited number of media content on the internet and consume intensively through mobile phones, tablets and computers may have consequences on family relations and communication styles. The education and awareness raising of parents on digital media literacy is an important part of media literacy education. Today, it is a necessity for the family members of all ages to be a conscious media literate in order to avoid social and individual problems and risks in their relations with digital technologies. Digital literacy aims to minimize the negative aspects of communication technologies by developing positive features. Experts conduct important discussions on the problems and risks of digital media usage and a qualified digital media literacy is recommended as one of the indispensables of our time. In this context, in this study, there is a discussion about why parents should be digital media literate, the effects of digital media on family relations and child development, the contribution of digital literate parents to family relations and child education.

Nowadays, children need to learn to use the media for more conscious, useful and scientific purposes in order to be able to grow as a healthy individual in physical, mental and intellectual terms. It will be possible for children to be affected by the negative effects of digital media at a minimum level, and for parents who are closest to children need to become conscious digital media literate. The lack of digital media literacy skills of parents and the lack of studies on the education of parents on this issue is an important obstacle in the development of children's digital media literacy awareness and skills. 
In recent researches, it has been shown that digital media means have been used extensively and there has been a negative change in family relations. The fact that family members spend a continuous time in front of mobile phones, television and computer screens and consume media program contents intensively has reduced their time for each other, weakened their communication, reduced domestic affection and attention, face-toface relationships, loneliness, depression and divorce. has brought the problem (Batıgün and Kılıç 2011; Çetinkaya and Sütçü, 2016; Demir, 2016; Kraut and et. al, 1998;). In addition to the effects of digital media on family relations, it has been shown that it has significant effects on the physical, mental and mental development of the child (Çakıral, 2016; İnal, 2015; Şirin, 2015). Children's habits of watching television and using internet technologies begin very early and they spend most of their time in front of these screens. Digital media could teach children virtual socialization, some ideological cultural values, a consumer lifestyle and a violence and sexist culture. While digital media can affect children's communication styles, playing environments and ways of being informed, they can also have negative effects on children's imagination, reasoning, reasoning and effective speaking abilities (Akçalı, 2015; İnal, 2015; Öztürk, 1999).

Parents in the family are concerned about the time and manner in which the child uses digital media. At the same time, the family is concerned about having the child close to his / her room, having little communication with family members, being withdrawn, asocializing, not having a chat, disruption of sleep and feeding habits, gaining weight and still life. Children are more likely to use the internet for gaming and entertainment rather than research. This causes problems such as children not working at home, not doing their homework, having difficulty in studying, decreasing school success and not reading books.

Digital media literacy is a process of gaining communication skills including access to all kinds of writing, audio and visual news, information, verifying, understanding, perceiving, analyzing, converting and sharing these kinds of articles, audiovisual and visual news on the internet by means of computers, tablets and smart phones. The education of the parents on digital media literacy will provide the ability to regulate, control and manage the problems experienced in the family relations arising from the use of digital technology. Another contribution of literacy education 
to parents will contribute to children's awareness of choosing, using, criticizing and protecting digital media. This contribution of parents will enable children to be better motivated and more willing and successful in the media literacy class they will take during school.

Children's habits of watching television, using internet and mobile phones, using social media, and playing online games can be regulated by family education. With the family's digital literacy training, children's time to watch digital media, their ability to be selective in programs, their level of imitation of the people they see can be regulated and will form an important basis for the child's future literacy education at home and school. It is an important requirement for parents to be a successful role model in digital media literacy and to receive relevant training. Children of parents who are not educated in digital media literacy and who do not develop awareness are at risk of being dependent on digital media and being exposed to all kinds of negative effects. The establishment of a healthy communication environment between parents and children, the development of the child's personality in a positive way, requires parents to be digital media literate. Parents will be able to regulate their children's use of digital tools with their education on digital media literacy, and will contribute to their perception of the content produced in the internet and television environments correctly, to protect them from these contents and to realize the difference between reality and fiction. Children are at risk of emotional, mental and social development if their parents fail to regulate the use and duration of digital media.

It is clear that there is a need for an adult to guide children and set limits for the use of digital media. The main responsibility of digital media education of children and adolescents belongs first to the family, where their development started. Inan (2013) states that the education of the parents who will play an indirect or direct role in the development of children's media literacy skills is insufficient. İnan expresses how and to what extent children are affected by the mass media, how their parents' attitudes are from the point of view of the children, and what the parents think about the problems they face due to their children's use of the mass media can form the basis of home and school-based intervention plans. Güneş (2013), on the other hand, says that non-governmental organiza- 
tions and media organizations should also include the issue of digital media literacy in their agenda in order to protect the child's mental health. At the same time, the importance given to the issue by the state organs and support to the studies carried out in this field emphasizes the social state responsibility. It is necessary to increase the parents' interest towards digital media literacy and contribute to their understanding of children's media activities in Turkey. It should be underlined that the issue of digital media literacy education of children is also a matter of a child and family relationship. When the studies on the issue of digital media literacy are evaluated it is observed that there are important deficiencies of the parents' information about the digital world and there is a striking gap in this issue in Turkey.

\section{Kaynakça / References}

Akçalı, S. İ. (2015). Tüketim toplumunda çocukluğun yitişi. (S. İ. Akçalı Ed.). Çocuk ve medya, içinde (s. 21-13 ). Ankara: Nobel Yayınları.

Aytaş, G. ve Kaplan, K. (2017). Medya okuryazarlığı bağlamında yeni okuryazarlıklar. Ahi Evran Üniversitesi Kırşehir Ĕ̆itim Fakültesi Dergisi, 18(2), 291-310.

Batıgün, A. D. ve Kılıç, N. (2011). İnternet bağımlılı̆̆ı ile kişilik özellikleri, sosyal destek, psikolojik belirtiler ve bazı sosyo-demografik değişkenler arasındaki ilişkiler. Türk Psikoloji Dergisi, 26(67), 1-10.

Batmaz, V. ve Aksoy, A. (1995). Türkiye'de televizyon ve aile:Elektronik hane. Ankara: Bizim Büro Basımevi.

Browne, N. (1999). Young children's literacy development and the role of televisual texts. New York, NY: Falmer Press.

Çakıral, M. (2016). Televizyon kıskacında çocuk ve subliminal mesajlar. İstanbul: Ferfir Yayıncllık.

Çetinkaya, L. ve Sütçü, S. S. (2016). Çocukların gözüyle ebeveynlerinin bilişim teknolojileri kullanımlarına yönelik kısıtlamaları ve nedenleri. Turkish Online Journal of Qualitative Inquir, 7(1), 79-116.

Demir, U. (2016). Sosyal medya kullanımı ve aile iletişimi: Çanakkale'de lise öğrencileri üzerine bir araştırma. Selçuk İletişim Dergisi, 9(2), 27-50.

Demiriz, S. ve Öğretir, A. D. (2007), Alt ve üst sosyo-ekonomik düzeydeki 10 yaş çocuklarının anne tutumlarının incelenmesi. Kastamonu Eğitim Dergisi, 15(1), 105-122. 
Dijilopedi (2018). 2018 Türkiye internet kullanım ve sosyal medya istatistikleri. 15 Haziran 2019 tarihinde https://dijilopedi.com/2018-turkiye-internetkullanim-ve-sosyal-medya-istatistikleri/ adresinden erişildi.

Gül, G. (2007). Okuryazarlık sürecinde aile katılımının rolü. Ankara Üniversitesi Ĕ̆itim Bilimleri Fakültesi Özel Ĕ̆itim Dergisi , 8(1), 17-30.

Güleç, N. (2019). Kritik ve analitik düşünme perspektifinde dijital medya okuryazarlı̆̆ı. 20 Haziran 2019 tarihinde http://www.kadinveaile.com/kritikve-analitik-dusunme-perspektifinde-dijital-medya-okuryazarligi-2/ adresinden erişildi.

Güleç, V. (2018). Aile ilişkilerinin sosyal medya ile birlikte çöküşü. Yeni Medya Elektronik Dergi, 2, 105-120.

Güneş, A. (2013). Medya Pedagojisi. (H. Yavuzer, ve M.R. Şirin, Ed.). I. Türkiye Çocuk ve Medya kongresi bildiriler kitabı, içinde (s. 83-98 ). İstanbul: Çocuk Vakfı Yayınları.

Hazar, M. (2011) Sosyal medya bağımlılı̆̆ı: Bir alan çalışması. İletişim Kuram ve Araştırma Dergisi, 3, 158 - 159.

Hobbs, R. (2010). Digital and media literacy: A plan of action. 12 May1s 2019 tarihinde https://works.bepress.com/reneehobbs/13 adresinden erişildi.

İnal, K. (2015). Türkiye'de çocukluk nereye. (S. İ. Akçalı Ed.), Çocuk ve medya. içinde ( s. 13-51 ). Ankara: Nobel Yayınları.

İnan, T. (2013). Medya okuryazarlı̆̆ı sürecinde medya, çocuk ve ebeveyn ilişkisi: ortaokul ögrencilerinin ve ebeveynlerinin televizyon ve internet kullanımlarına ilişkin tutum ve davranışlarının incelenmesi. Yayınlanmamış yüksek lisans tezi, Dumlupınar Üniversitesi, Kütahya.

İrvan, A. A. (2017). Dijital medya okuryazarlığı nedir? neden gereklidir? 20 Mayıs 2019 tarihinde https:/dijitalmedyavecocuk.bilgi.edu.tr/2017/06/06/dijital-medya-okuryazarligi-nedir-neden-gereklidir/ adresinden erişildi.

Kabakçı-Yurdakul, Işıl., Dönmez, O. Yaman, F. ve Ferhan ve Odabaşı, H. (2013). Dijital ebeveynlik ve değişen roller. Gaziantep University Journal of Social Sciences, 12(4), 883-896.

Kanat, S. (2016). Uluslararası ilişkiler yaklaşımları açısından dijital medya ve savaş. TRT Akademi Dergisi, 1(2), 528-546.

Kaya-Bensghir T. ve Altınok, R. (2012). Türkiye'de internetin aile içi ilişkilere etkisi. 20 Nisan 2019 tarihinde https:/www.tbmm.gov.tr/ arastirma_komisyonlari/bilisim.../ramazan_altinok.pptx adresinden erişildi. 
Kraut, R., Patterson, M., Landmark, V., Kiesler, S., Mukophadhyay, T. ve Scherlis, W. (1998) Internet paradox: A social technology that reduces social involvement and psychological well being?, American Psychologist, 53, 1017- 1031

Livingstone, S. ve Haddon, L. (2009). EU kids onlin: Final report. 5 Nisan 2019 tarihinde http://www.lse.ac.uk/media@lse/research/EUKidsOnline/EU\%20Kids\%20I\%20(2006-

9)/EU\%20Kids\%20Online\%20I\%20Reports/EUKidsOnlineFinalReport.pdf adresinden alınmıştır.

Medya okur yazarlığ1 ebeveynleri de kapsayacak (2012). Milliyet. http://www.milliyet.com.tr/pembenar/medya-okur-yazarligi-ebeveynleri-de-kapsayacak-1529827

Gençlerin yüzde 3,6'sı internet bağımlısı. (2017). NTV. 20 Mayıs 2019 tarihinde https://www.ntv.com.tr/teknoloji/genclerin-yuzde-3-6si-internetbagimlisi,orBTeQTwx0KUB05JYTQ8sA adresinden erişildi.

Özel, E., ve Zelyurt, H. (2016). Anne baba eğitiminin aile çocuk ilişkilerine etkisi. Sosyal Politika Çalışmaları Dergisi, 16(36), 9-34.

Özgüven, İ. E. (2001). Ailede iletişim ve yaşam. Ankara: PDREM Yayıncılık.

Özkan, A. (2016). Dijital medya ve çocuk: sosyalleşmenin yeni boyutları. Yayınlanmamış yüksek lisans tezi. Sakarya Üniversitesi, Sakarya.

Öztürk, E.H. (1999). Çocuğun sosyalleşmesinde televizyonun etkisi. Yayınlanmamış Doktora Tezi, Sakarya Üniversitesi, Sakarya.

Özyürek, A. ve Şahin, F. T. (2005). 5-6 Yaş grubunda çocuğu olan ebeveynlerin tutumlarının incelenmesi. Gazi Ĕ̆itim Fakültesi Dergisi, 25(2), 19-34.

Roberts, D. F., Foehr, U.G. ve Rideout, V. (2005). Generation M: Media in the lives of 8-18 year olds. Menlo Park, CA: Kaiser Family Foundation.

RTÜK (2016). Medya okuryazarlığı araştırması. 20 Haziran 2019 tarihinde https://www.rtuk.gov.tr/assets/Icerik/AltSiteler/medya-okuryazarligi-arastirmasi.pdf adresinden erişildi.

Serhatlığlu, B. (2006). Televizyon programlarının okul öncesi eğitim kurumuna devam eden 5-6 yaş grubu çocuklarmm zihin ve dil gelişimini etkileme biçimlerine yönelik öğretmen ve veli görüşlerinin belirlenmesi. Yayımlanmamış Yüksek Lisans Tezi, Fırat Üniversitesi, Elazığ.

Şirin, M. R. (2015). Televizyon, çocuk ve aile. İstanbul: İz Yayıncllık.

Tan, O. (2015). Medya okuryazarlı̆̆ı eğitimi: öğrenci, öğretmen, aile bağlaminda örnek bir araştırma. Yayınlanmamış yüksek lisans tezi, Akdeniz Üniversitesi, Antalya. 
Dijital oyun bağımlılı̆̆ı 'hasta' ediyor., (2017). Türkiye Gazetesi. 20 Mayıs 2019 tarihinde https://www.turkiyegazetesi.com.tr/saglik/611233.aspx adresinden erişildi.

Ulusoy, A. ve Bostancı, M. (2014). Çocuklarda sosyal medya kullanımı ve ebeveyn rolü. The Journal of Academic Social Science Studies, 28, 559-572.

UNICEF. (2017). Dünya çocuklarının durumu 2017, 12 Mayıs 2019 tarihinde http://www.unicef.org.tr/files/bilgimerkezi/doc/SOWC_2017_SUM_TR.pdf adresinden alınmıştır.

Warren, R. (2001). In words and deeds: Parental involvement and mediation of children's television viewing. Journal of Family Communication, 1, 211-231.

\section{Kaynakça Bilgisi / Citation Information}

Karaboğa, M. T. (2019). Dijital medya okuryazarlı̆̆ında anne ve baba eğitimi. OPUS-Uluslararası Toplum Araştırmaları Dergisi, 14(20), 2040-2073. DOI: 10.26466/opus.601942 